\title{
Technical Note: A technique for conducting small-plot burn treatments
}

\author{
JOHN L. KORFMACHER, JEANNE C. CHAMBERS, ROBIN J. TAUSCH, BRUCE A. ROUNDY, SUSAN E. \\ MEYER, AND STANLEY KITCHEN
}

Authors are, respectively, Ecologist, Research Ecologist, and Project Leader, USDA Forest Service, Rocky Mountain Research Station, Reno Forestry Sciences Laboratory, 920 Valley Rd., Reno, Nev. 89512; Professor, Dept. of Botany and Range Science, Brigham Young University, Provo, Ut. 84602; Ecologist and Botanist, USDA Forest Service, Rocky Mountain Research Station, Shrub Sciences Laboratory, 735 N $500 E$, Provo, Ut. 84606.

\begin{abstract}
An experimental design required burn treatments for $10-\mathrm{m}^{2}$ circular plots. We constructed a fire enclosure for the plots using sheetmetal, electrical conduit, and other commonly available materials. We field tested the enclosure in sagebrush-grass ecosystems in central Nevada and central Utah, and evaluated peak fire temperatures using small metal tags striped with temperature sensitive paint. We obtained average peak surface temperatures of 310,307 , and $381^{\circ} \mathrm{C}$ in bare ground, under grass, and under shrub microsites, respectively, for the Nevada sites and 253,299 , and $337^{\circ} \mathrm{C}$ for the same microsites, respectively, in Utah. Subsurface $\left(2-\mathrm{cm}\right.$ depth) temperatures rarely exceeded $7^{\circ}$ $C$, the lowest temperature detectable by our method. The enclosure contained the fire and did not permit escape of any embers or firebrands. The fire enclosure, burn technique and temperature monitoring method used are inexpensive, easily deployed, and desirable for experiments where larger-scale burns are impractical.
\end{abstract}

Key Words: Fire, Great Basin, sagebrush, burn barrel, temperature, temperature monitoring

The consequences and benefits of wildland fire have recently received greater attention from researchers and land managers, particularly in the western U.S. Effects of large wildland fires or prescribed burns can be examined without the use of experimental equipment at any spatial scale, but experiments at smaller (i.e., microhabitat) spatial scales often require control and monitoring of fire effects and environmental factors. In many of these experiments, it is necessary to restrict fire effects to small study plots, prevent disturbance of nearby control plots, maintain control of the fire, and ensure worker safety. This technical note describes a

We thank Ben Rau, Lorie Haselhorst, Leigh Metcalf, Allison Whittaker, Susan Garvin, and Stephanie Carlson, and Dan Symmes for technical assistance, and Dave Turner for statistical advice. We also thank Laurence Crabtree, Dave Haney, and the Mountain City fire crew of the Humboldt-Toiyabe National Forest; and Dave Davis and the Austin fire crew of the Battle Mountain District, Bureau of Land Management, for support in conducting the burn treatments. We thank Robert Blank and two anonymous reviewers for their help in improving the manuscript.

The use of trade or firm names in this paper is for reader information and does not constitute endorsement by the US Department of Agriculture of any product or service. This work was funded in part by Joint Fire Sciences Program,

Manuscript accepted 13 Jul 02.

\section{Resumen}

Un diseño experimental requirió tratamientos de quema en parcelas circulares de $10 \mathrm{~m}^{2}$. Construimos una exclusión contra fuego para las parcelas utilizando hojas de metal, tubos metálicos para conducción de cables de electricidad (conduit) y otros materiales comúnmente disponibles. Probamos la exclusión en campo en ecosistemas de "Sagebrush-zacate" de la región central de Nevada y Utah y evaluamos las temperaturas pico del fuego usando pequeñas etiquetas de metal marcadas con pintura sensible al calor. En los sitios de Nevada obtuvimos una temperaturas pico promedio de la superficie de 310,307 y $381^{\circ} \mathrm{C}$ en suelo desnudo, bajo el zacate y en los micrositios de los arbustos respectivamente, en tanto en Utah registramos 253,299 y $337^{\circ} \mathrm{C}$ respectivamente para los mismos micrositios. Las temperaturas subsuperficiales $(2 \mathrm{~cm}$ de profundidad) raramente excedieron $\operatorname{los} 79^{\circ} \mathrm{C}$, esta fue la temperatura mas baja detectable por el nuestro método. La exclusión contuvo el fuego y no permitió el escape de rescoldos ni llamaradas. La exclusión para fuego, la técnica de quemado y el método de monitoreo de temperatura son baratos, fácilmente desplegados y deseables para experimentos donde las quemas a gran escala son imprácticas.

portable device and procedures for conducting small-plot burn treatments, and a convenient and inexpensive method of monitoring peak fire temperatures.

Many studies examine effects on small plots in the context of larger fire events. For example, Perez and Moreno (1998) examined $1 \times 1 \mathrm{~m}$ plots inside a $3 \times 22 \mathrm{~m}$ burn plot. Other studies established small plots in an area being prepared for a large prescribed burn (Cole et al. 1992), or in areas later subjected to wildfire (Kutiel and Inbar 1993). Restricting fire to the limits of a plot also can be effected by arrangement of fuel in piles (e.g., Tanaka et al. 2001).

A number of fire enclosure or burning devices have been developed for various purposes. Wright and Klemmedson (1965) fabricated a combustor out of a 208-liter ("55-gallon") size drum that used shredded paper for fuel, and used the device to burn individual plants. Propane-fired burners are also in use, in sizes up to $107 \mathrm{~cm}$ in diameter (Britton and Wright 1979). However, it is not practical to adapt either of these designs for use on larger (3-5 m diameter) plots.

Knowledge of fire characteristics is important to understanding post-fire vegetation dynamics and soil chemical characteristics and processes (Wright and Bailey 1982, Whelan 1995). Fire 
effects can be evaluated by collecting data on the intensity and duration of the fire or by observing fire parameters such as energy release, flame length, and residence time (Sapsis and Kauffman 1991). Ideally, this information is collected using thermocouples linked to data recorders (e.g., McDaniel et al. 1997) or evaluated using time-temperature curves and fuel loading for a particular fuel type (e.g., Wright et al. 1976). However, limitations imposed by study design, time, or other factors may make these methods impractical. A simpler, more economical method uses temperature-sensitive tablets ("Tempils"), which melt at certain temperatures (Shearer 1975). Temperature-sensitive paint, applied to ceramic tiles or mica plates (Gibson et al. 1990) or to aluminum tags (Cole et al. 1992) permits a large number of sensors for coverage of extensive areas or high sampling density. These methods do not permit a rigorous evaluation of the range of fire effects, but they are useful for examining 2- or 3-dimensional spatial variability of fire intensity (Cole et al. 1992).

\section{Materials and Methods}

Our fire enclosure (Fig. 1) was designed to treat a circular, 3.4-m diameter plot, prevent escape of embers and firebrands, be easily lifted and carried by 3-4 workers, and be transported in a standard-bed pickup truck. All materials used in assembly of the enclosure were purchased at local hardware stores. It was constructed of 16 panels of corrugated sheetmetal, each $122 \times 61 \mathrm{~cm}$, with $1-\mathrm{cm}$ gaps between panels for ventilation. For ease of transport and field portability, the enclosure was constructed in 4 sections of 4 panels each. The panels are joined by $3.8-$ $\mathrm{cm}$ (1.5-inch) hinges. Each section of 4 panels was reinforced by two, 244-cm lengths of $1.9-\mathrm{cm}(0.75$-inch) diameter electrical conduit that were shaped on a plumber's pipe bender. The reinforcements were attached to the panels at $10 \mathrm{~cm}$ from the top and bottom edges with bolts on $30-\mathrm{cm}$ centers. The sections were joined by short lengths of $2.5-\mathrm{cm}$ (1-inch) electrical conduit and straight pins (Fig. 2). To make a screen for the top of the fire enclosure, we assembled a framework from four, $180-\mathrm{cm}$ long angle irons bolted together in the center and reinforced by a $2.5 \times 40 \times 0.5 \mathrm{~cm}$ piece of steel. We attached $0.6-\mathrm{cm}(0.25$-inch $)$ hardware cloth, cut to a circular shape, to this framework. All fasteners used were standard

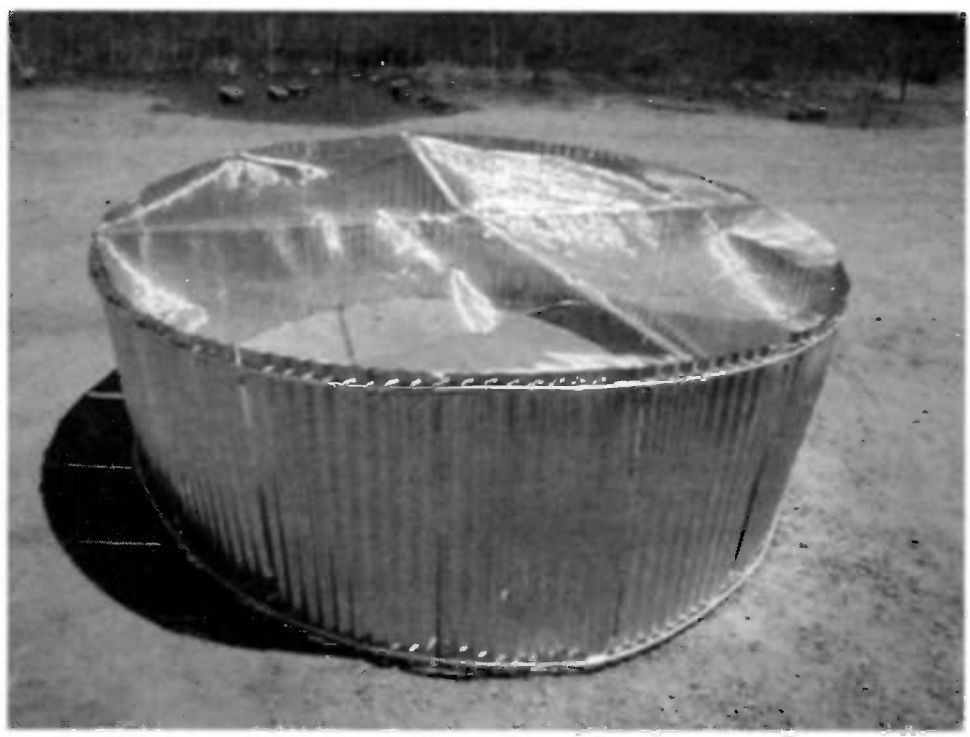

Fig. 1. A photograph of the $3.4 \mathrm{~m}$ diameter fire enclosure.

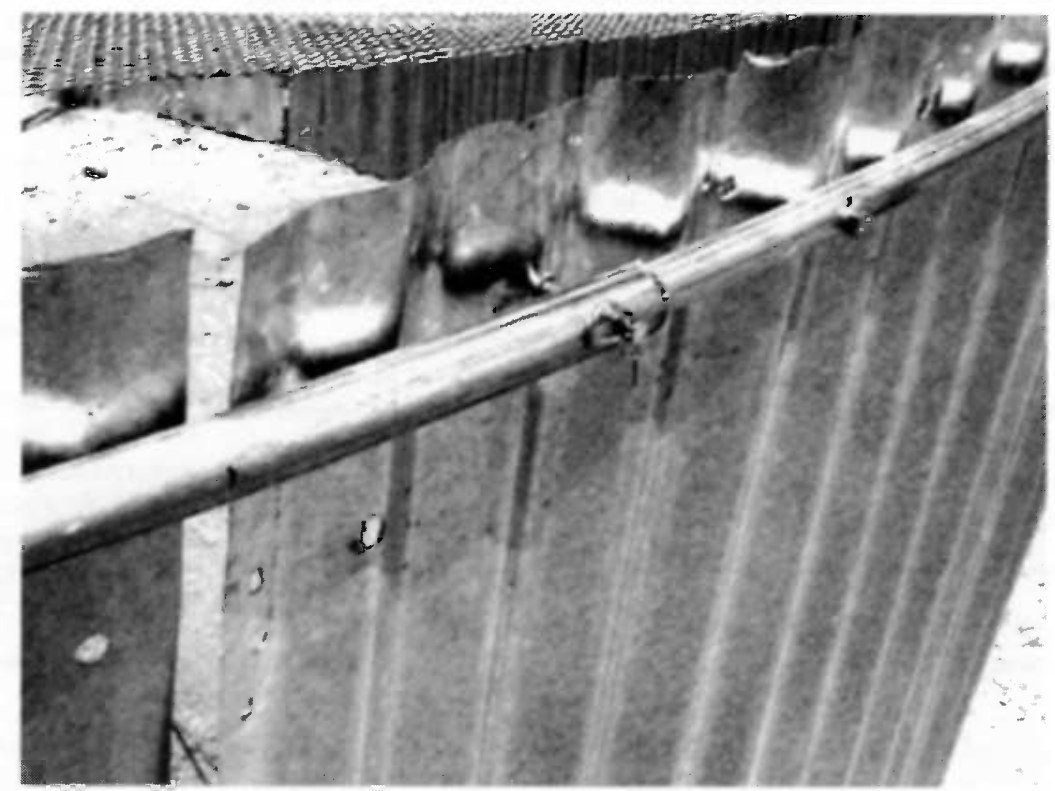

Fig. 2. Detail of pins and different-diameter electrical conduit used to connect the panels of the fire enclosure.

SAE sizes. Each section weighs $<20 \mathrm{~kg}$ and can be easily carried by 1 person. The materials cost $\$ 284$ and required about 20 worker-hours to construct.

We chose ungalvanized, 28-gauge sheetmetal as the material for our temperature monitoring tags. This material is preferable to aluminum because of its higher melting temperature and low cost. However, as a conductor, it is also subject to a brief "lag" in response to temperature changes as described by Cole et al. (1992). Tags were cut to $2.5 \times 10 \mathrm{~cm}$ size and striped with 20 Tempilaq $^{\circledR}$ temperature sensitive paints (Tempil, Inc., $\mathrm{S}$. Plainfield, N.J.) in ascending order of sensitivity, from $79-788^{\circ} \mathrm{C}$. The typical tem- perature interval between paints was $28^{\circ}$ C. We used a plant press to transport the tags as the paint strips are somewhat fragile when dry. Each tag cost about $\$ 0.10$ for materials and required about 2 minutes of labor to produce.

We used the fire enclosure to conduct burn treatments on circular, 3.4-m diameter plots as a component of a study of cheatgrass response (Bromus tectorum L.) to fire in central Nevada and central Utah. We conducted the burns in early October and mid-November, 2001 on the Nevada and Utah sites, respectively. The Nevada study area was in the Shoshone Range, on the Humboldt-Toiyabe National Forest, at $39^{\circ}$ north latitude, $117^{\circ} 30^{\prime}$ west longi- 
tude. Three sites were located in Underdown Canyon, at 1,950, 2,190, and 2,380 m elevation, and a fourth site was at the mouth of Barrett Canyon at 2,065 m. Vegetation (taxonomy after USDA Forest Service 2002) on the 1950-m site consisted of Wyoming sagebrush (Artemisia tridentata Nutt. ssp. wyomingensis Beetle \& Young) with an understory of Sandberg bluegrass (Poa secunda J. S. Presl. var. secunda), needle-and-thread grass (Hesperostipa comata (Trin. \& Rupr.) Barkworth), bottlebrush squirreltail (Elymus elymoides (Raf.) Swezey) and cheatgrass. At the 2380-m site, the dominant shrub was mountain big sagebrush (Artemisia tridentata ssp. vaseyana (Rydb.) Beetle), cheatgrass was absent and Idaho fescue (Festuca idahoensis Elmer) was a significant understory component. The $2,190-\mathrm{m}$ site had vegetation components of both the 1,950-m and 2,380-m sites. The Barrett Canyon site was cleared and overseeded with crested wheatgrass (Agropyron cristatum (L.) Gaertn.) in the early 1960's. Crested wheatgrass was the dominant plant on this site with a sparse cover of Wyoming big sagebrush. Precipitation for the water year (mid-Oct. 2000 to mid-Oct. 2001) preceding the treatments ranged from $14 \mathrm{~cm}$ at $2,000 \mathrm{~m}$ elevation to $28 \mathrm{~cm}$ at $2,400 \mathrm{~m}$, and was well below annual average for these types of sites (USDA Forest Service unpublished data). The Utah study area was in the East Tintic Range, on land administered by the Bureau of Land Management, at $40^{\circ}$ north latitude, $112^{\circ}$ west longitude. Three sites were located at 1,710 m, ,2085 m (Black Rock Canyon) and 2,270 m (Mill Canyon) elevation. Vegetation on the lowest site was dominated by Wyoming big sagebrush and bluebunch wheatgrass (Pseudoroegneria spicata (Pursh) A. Löve). The dominant shrub on the 2 upper sites was mountain big sagebrush, with Fendler bluegrass (Poa fendleriana (Steud.) Vasey) and spike fescue (Leucopoa kingii (S. Wats.) W.A. Weber) present on the 2,085-m and 2,270-m sites, respectively. Precipitation data for the Utah sites were not available.

Pre-burn moisture content of fuels at the Nevada sites ranged from $20.4-36.1 \%$ for needle-and-thread grass. For sagebrush, we evaluated leaves, $0.5-2.5 \mathrm{~cm}$ diameter, and $2.5-7.5 \mathrm{~cm}$ diameter fuels, which contained 43.3-50.9\%, 8.6-16.2\%, and 8.6$9.0 \%$ moisture by weight, respectively. The latter 2 categories correspond approximately to 10-hour and 100-hour fuels (after Wright and Bailey 1982). We did not collect fuel moisture data on the Utah sites. Air temperature during the treatments in Nevada ranged from $12-20^{\circ} \mathrm{C}$ and relative humidity was $15-25 \%$. Air temperature and humidity ranges for the Utah treatments were $13-16^{\circ} \mathrm{C}$ and $30-47 \%$. Fuel loading was generally low, especially at the lower elevation sites. To ensure uniform burn characteristics, we dispersed $4.5 \mathrm{~kg}$ of dry straw in each plot, yielding a fuel loading of $>5000 \mathrm{~kg} \mathrm{ha}^{-1}$ on all plots.

We burned 9 plots on each of the 7 sites. Before conducting the burns, we cleared all woody vegetation within $0.5 \mathrm{~m}$ of the plot. We placed temperature tags on 3 microsites (under shrub, under grass, and on bare ground) and at 2 depths (on the litter surface, or on the soil surface if no litter was present; and $2 \mathrm{~cm}$ below the soil surface) within each microsite, for a total of 6 measurements per plot. We marked the tag locations with steel rods. We then positioned the enclosure, added the straw, moistened the periphery of the enclosure with a mister nozzle, and ignited the plot with a drip torch containing a diesel/gasoline mix. We allowed 15 minutes on the low elevation plots and 25 minutes on the high elevation plots for fuels to be consumed, and then quenched the entire plot with the mister nozzle, taking care not to disturb the soil. We recovered the temperature monitoring tags and recorded the number of paint strips remaining on the tags.

A preliminary analysis indicated the data would be best suited to nonparametric statistical methods. We used the Multiple Response Permutation Procedure (MRPP) to analyze the temperature data (Mielke et al. 1976, Petrondas and Gabriel 1983). Significance values indicate the probability of a smaller MRPP test statistic $(\mathrm{P}[<\delta])$.

\section{Results and Discussion}

The fire enclosures were effective in containing the fire for the fuel loading $\left(\sim 5000 \mathrm{~kg} \mathrm{ha}^{-1}\right)$ in the study. Despite occasional flame lengths of up to $5 \mathrm{~m}$, no escape or "spotting" occurred. The under shrub microsite exhibited significantly higher peak surface temperatures than bare ground or under grass microsites (Fig. 3),
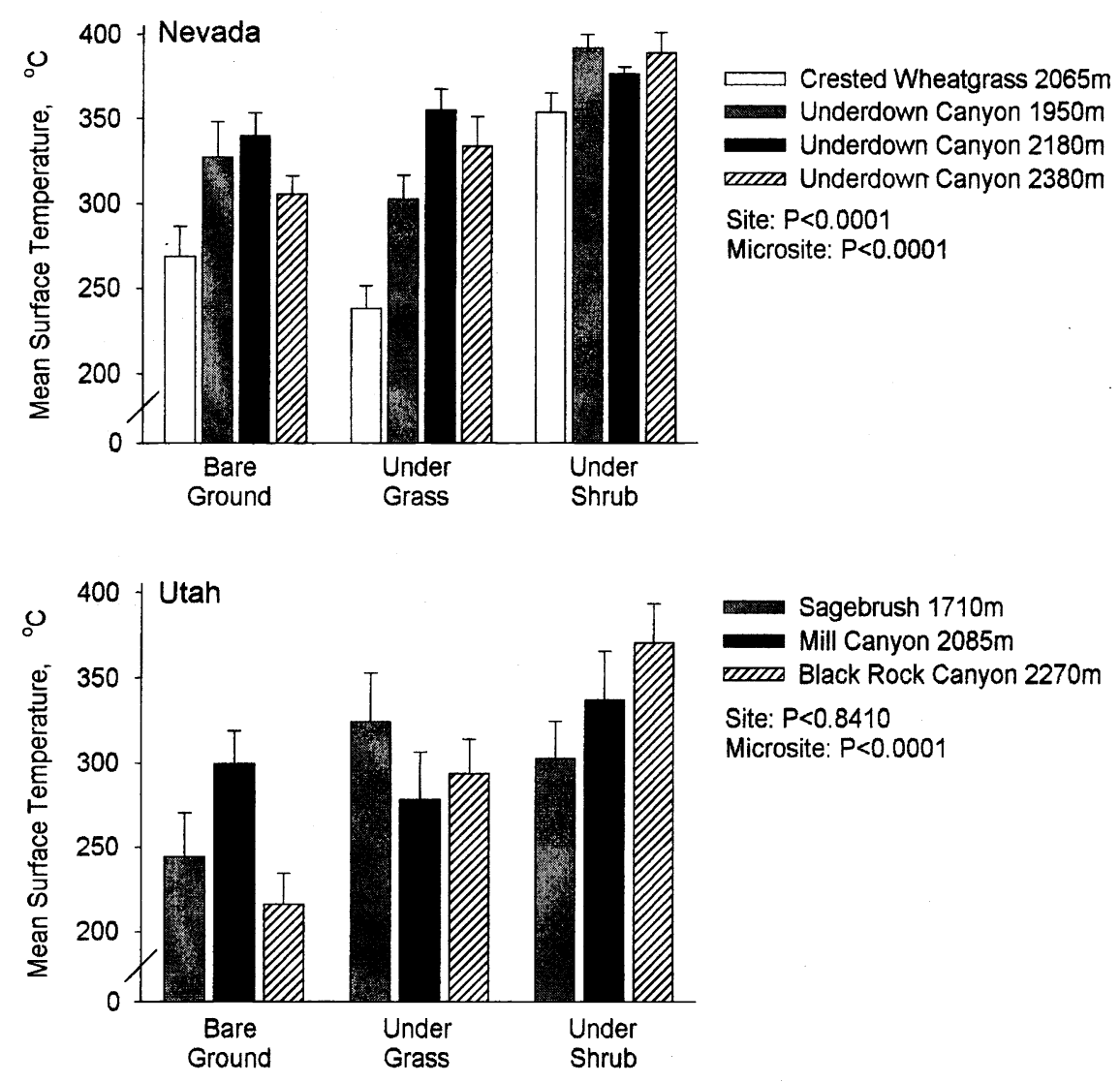

Fig. 3. The differences in the surface temperatures $\left({ }^{\circ} \mathrm{C}\right)$ among bare ground, under grass, and under shrub microsites on the study sites in Nevada and Utah. Values are mean+S.E. 
averaging $381^{\circ} \mathrm{C}$ versus 310 and $307^{\circ} \mathrm{C}$, respectively ( $\mathrm{P}<0.0001$ for both comparisons) at the Nevada sites, and $337^{\circ} \mathrm{C}$ versus 299 and $253^{\circ} \mathrm{C}$, respectively $(\mathrm{P}=$ 0.0176 and $\mathrm{P}<0.0001)$ at the Utah sites. We attribute the difference to the higher fuel loading of the under shrub microsite, and to woody embers falling on or near the tags. The difference in peak surface temperatures for the other 2 microsites (under grass and bare ground) was not significant at the Nevada sites, but was significant on the Utah sites $(\mathrm{P}=0.0175)$. There were no significant differences in peak surface temperatures among the 3 sites in Underdown Canyon (Nevada), or among the 3 Utah sites, but the Barrett Canyon (Nevada) crested wheatgrass site was cooler overall than the Underdown Canyon sites $(\mathrm{P}=0.0008, \mathrm{P}<0.0001$, and $\mathrm{P}$ $=0.0003$ for pairwise comparisons with the Underdown 1950-, 2190-, and 2380-m sites, respectively). Differences in fuel loading between these 2 microsites were probably minimized by the addition of straw. Overall, peak surface temperatures averaged $51^{\circ} \mathrm{C}$ higher $(\mathrm{P}<0.0001)$ on the Nevada sites than on the Utah sites. We attribute this to the later date and cooler, wetter conditions prevailing for the Utah burns.

Peak temperatures for tags at the $2-\mathrm{cm}$ depth were generally below $79^{\circ} \mathrm{C}$, the lowest detectable temperature. We deployed 160 tags at the $2-\mathrm{cm}$ depth, only 54 of which recorded temperatures above $79^{\circ} \mathrm{C}$. Most $(70 \%)$ of the 54 readings above $79^{\circ} \mathrm{C}$ were in the under shrub microsite.

The peak surface temperatures detected in this test were within the ranges reported for snowberry shrubland (Bailey and Anderson 1980), chaparral (DeBano et al. 1977) and sandhill grassland (Gibson et al. 1990). They were consistent with temperature ranges used in laboratory experiments simulating rangeland fire effects (Blank and Young 1998, Blank et al. 1994). The lack of temperature responses at the $2-\mathrm{cm}$ depth was probably due to the insulating effect of the soil, and was consistent with subsurface temperatures noted in Australian shrubland (Bradstock et al. 1992) and chaparral (DeBano et al. 1977).

The small plot fire enclosure described here can be inexpensively constructed with readily available materials, easily transported and efficiently deployed in the field. It effectively prevents spread of fire to nearby plots or to the surrounding landscape. The plot burning and fire temperature assessment methods are also simple and inexpensive. The techniques are not adequate where precision control of fire temperatures and absolutely uniform heat distribution are required, or where researchers desire precise knowledge of the timing and magnitude of temperature changes, but they are adequate for evaluating the spatial variability of burn intensity. They are appropriate to research where a relatively uniform burn treatment is desired, but funds, study design, or time do not permit larger burns, pre-burn standing crop estimation, or more elaborate temperature monitoring.

\section{Literature Cited}

Bailey, A.W. and M.L. Anderson. 1980. Fire temperatures in grass, shrub and aspen forest communities of central Alberta. J. Range Manage. 33:37-40.

Blank, R.R. and J.A. Young. 1998. Heated substrate and smoke: Influence on seed emergence and plant growth. J. Range Manage. 577-583.

Blank, R.R., F. Allen, and J.A. Young. 1994. Extractable anions in soils following wildfire in a sagebrush-grass community. Soil Sci. Soc. Amer. J. 58:564-570.

Bradstock, R.A., T.D. Auld, M.E. Ellis, and J.S. Cohn. 1992. Soil temperatures during bushfires in semi-arid, mallee shrublands. Aust. J. Ecol. 17:433-440.

Britton, C.M. and H.A. Wright. 1979. A portable burner for evaluating effects of fire on plants. J. Range Manage. 32:475-477.

Cole, K.L., K.F. Klick, and N.B. Pavlovic. 1992. Fire temperature monitoring during experimental burns at Indiana Dunes National Lakeshore. Natur. Areas J. 12:177-183.

DeBano, L.F., P.H. Dunn, and C.E. Conrad. 1977. Fire's effect on physical and chemical properties of chaparral soils. In: H.A. Mooney and C.E. Conrad (tech. coords.) Proceedings of the symposium on the environmental consequences of fire and fuel management in Mediterranean ecosystems. USDA Forest Serv. Gen. Tech. Rep. WO-3.

Gibson, D.J., D.C. Hartnett, and G.L.S. Merrill. 1990. Fire temperature heterogeneity in contrasting fire prone habitats: Kansas tallgrass prairie and Florida sandhill. Bull. Torrey Bot. Club 117:349-356.

Kutiel, P. and M. Inbar. 1993. Fire impacts on soil nutrients and soil-erosion in a Mediterranean pine forest plantation. Catena 20:129-139.

McDaniel, K.C., C.R. Hart, and D.B. Carroll. 1997. Broom snakeweed control with fire on New Mexico blue grama rangeland. J. Range Manage. 50:652-659.

Mielke, P.W. Jr., K.J. Berry, and E.S. Johnson. 1976. Multi-Response Permutation Procedures for a priori classifications. Communications in Statistics: Theory and Methods A14:1409-1424

Perez, B. and J.M. Moreno. 1998. Methods for quantifying fire severity in shrubland fires. Plant Ecol. 139:91-101.
Petrondas, D.A. and K.R. Gabriel. 1983. Multiple comparisons by rerandomization tests. J. Amer. Statistical Assoc. 78:949-957.

Sapsis, D.B. and J.B. Kauffman. 1991. Fuel consumption and fire behavior associated with prescribed fires in sagebrush ecosystems. Northw. Sci. 65:173-179.

Shearer, R.C. 1975. Seedbed characteristics in western larch forests after prescribed burning. USDA Forest Serv. Res. Paper INT-167. Ogden, Ut.

Tanaka, S., T. Ando, S. Funakawa, C. Sukhrun, T. Kaewkhongkha, and $K$. Sakurai. 2001. Effect of burning on soil organic matter content and $\mathrm{N}$-mineralization under shifting cultivation system of Karen people in northern Thailand. Soil Sci. Plant Nutr. 47:547-558.

USDA Forest Service. 2002. Fire Effects Information System Plant Database. Rocky Mountain Res. Sta., Fire Sci. Lab., Missoula, Mont. www.fs.fed.us/database/feis

Whelan, R.J. 1995. The ecology of fire. Cambridge Univ. Press, Cambridge, U.K

Wright, H.A. and A. W. Bailey. 1982. Fire ecology: United States and Southern Canada. John Wiley and Sons, New York, N.Y.

Wright, H.A. and J.O. Klemmedson. 1965. Effects of fire on bunchgrasses of the sagebrush-grass region in southern Idaho. Ecol. 46:680-688.

Wright, H.A., S.C. Bunting, and L.F. Neuenschwander. 1976. Effect of fire on honey mesquite. J. Range Manage. 29:467-471. 